\title{
Kryzys jako problem filozoficzno-społeczny
}

\section{ZARYS PROBLEMATYKI}

Interpretacje zjawiska kryzysu dotyczą najczęściej skutków ekonomiczno-gospodarczych. W warunkach integracji ekonomicznej, gospodarczej i bankowej takie podejście badawcze wydaje się być uzasadnione, ale zasięg oddziaływania kryzysu rozciąga się także na obszar relacji społecznych. Sfera życia społecznego z etycznego punktu widzenia budzi największy niepokój, bowiem skutki kryzysu mają bezpośredni wpływ na niesprzyjające nastroje społeczne, których źródeł należy upatrywać w załamaniu się gospodarki światowej. Negatywne skutki zjawiska kryzysu ujawniają swą obecność szczególnie wyraźnie na poziomie środowisk lokalnych, prowadząc choćby do innego zjawiska, mianowicie dywergencji społecznej. Mechanizmy, jakie w znacznej mierze przyczyniają się do tego typu przekształceń, to: kurczenie się rynku pracy, obniżenie dochodów czy zachodzące zmiany w zakresie świadomości i postrzeganiu zewnętrznych mechanizmów rynkowych jako obcych, groźnych i często niezrozumiałych.

W kontekście przedstawionych problemów warto zwrócić uwagę na fundamentalne znaczenie zjawiska kryzysu jako stanu oddziałującego negatywnie nie tyle na gospodarkę czy stan finansów, ale przede wszystkim na podmiotową kondycję psychiczną jednostek i społeczeństwa. Taką interpretację usprawiedliwia etymologia pojęcia „kryzys”, która

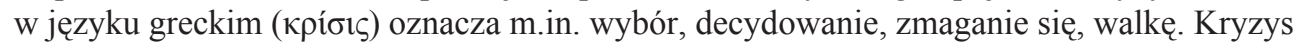
w tym rozumieniu jest więc działaniem w warunkach presji czasu. Obok tych treści słowo to oznacza także nagłość, punkt zwrotny (Słownik grecko-polski 2000, s. 557), urazowość i - co dla nas szczególnie interesujące - subiektywne konsekwencje urazu jako wynik negatywnych przeżyć.

W czasach płynnej nowoczesności każda egzystencja zdana jest na sieć zależności i różnego rodzaju powiązań. Otoczenie, jako środowisko naszego bytowania, konkretyzuje każdego w jakimś kontekście społecznym, czyniąc z tej zewnętrznej wobec nas przestrzeni określoną polistrukturę. W subiektywnym odczuciu jednostki jawi się ona jako niepewna, nieprzewidywalna i ryzykowna. Egzystencjalne niepokoje połączonych w sieć odniesień jednostek wypływają z przykrych doświadczeń w kontaktach z innymi, ale i otoczeniem ekonomiczno-społecznym, odbieranym jako obce i nieprzyjazne. W tak rozumianym środowisku, w którym obok akceptowanych wartości pozytywnych występują także negatywne i niepożądane, rodzą się wątpliwości, obawy i stan wewnętrznej dysharmonii. 
Kryzys jako zjawisko ekonomiczne, interpretowane w kategoriach załamania wzrostu gospodarczego, charakteryzuje się zmniejszeniem produkcji, realnych dochodów i wzrostem bezrobocia, jest skutkiem działań człowieka lub określonej grupy ludzi. O ile samo zjawisko kryzysu, w przeciwieństwie do jego następstw i rozmiarów, można przewidzieć i się go spodziewać (tendencje i wskaźniki ekonomiczne), to zachowań ludzkich przewidzieć niepodobna. Spojrzenie na kryzys w kategoriach przyczyny i skutku mieści w sobie pewien paradoks: jako negatywne zjawisko jest wywołane przez człowieka i w największym stopniu uderza właśnie w niego. Patrząc z perspektywy jednostki dotkniętej skutkami kryzysu, zarysowuje się obraz życia ludzkiego jako pasma ciągłych zmian i reorientacji, będących następstwem krytycznych wydarzeń. Na kryzys trzeba reagować. Jeśli przyjmiemy, że jest zjawiskiem z gruntu szkodliwym i społecznie niepożądanym, to i tak staje się źródłem nowych zachowań, wpływając tym samym na zmiany społeczne. Kryzys - przyczyna nowego, może więc być interpretowany jako pozytywny bodziec, nadający inne niż dotychczas kierunki i wyznaczający nowe cele. W czasach różnych kryzysów (nie tylko ekonomicznych) warto przyjrzeć się temu zjawisku, budując bardziej ogólną refleksję, która jeśli nie przyczyni się do jego zahamowania, to pozwoli je lepiej zrozumieć.

\section{KRYZYS JAKO NATURA}

Kryzys w odniesieniu do sensu greckiego ujawnia problem zmagania się oraz walki. Znaczenie to niewątpliwie najpełniej oddaje rezonans, jaki towarzyszy burzliwym załamaniom koniunktury w szeroko pojętym świecie biznesu. Jednak ściśle biorąc, moment walki i zmagań następuje dopiero wówczas, gdy sam kryzys już zaistniał, ukazując swe - najczęściej niekorzystne - skutki. Sytuacje kryzysowe, z którymi się zmagamy na co dzień, stanowią skutek zdarzeń losowych lub niepowodzeń i naszych porażek. W tym sensie nie wydaje się, abyśmy mogli bezkarnie skazywać to negatywnie konotujące się określenie jedynie na jego pejoratywny wydźwięk. Dlaczego?

Kryzys, jak chce tego większość słowników i encyklopedii, to stan załamania, nierównowagi, wahnięcia. Przez pojecie kryzysu gospodarczego rozumiem takie zjawiska ekonomiczne w gospodarce, które znacząco wpływają na nagłe pogorszenie się jej ogólnego stanu. Stan kryzysu gospodarczego charakteryzuje się falą bankructw instytucji finansowych oraz banków, której towarzyszą upadłości firm i przedsiębiorstw, czego wynikiem są zwolnienia grupowe, utrata miejsc pracy oraz redukcja etatów.

Zatem z punktu widzenia tzw. normy jest stanem nienormalnym, bo ukazującym odchylenie od założeń o charakterze normatywnym. To znaczy, że jest stanem a-normy zmuszającym nas nie tylko do działań na rzecz przywrócenia równowagi, ale i pouczającym na przyszłość o podobnych zdarzeniach oraz ich skutkach. Są one tyleż istotne, że dotyczą człowieka.

Każdy z nas, jako egzystencja, ulega ciagłym zmianom w następstwie kryzysowych wydarzeń. Bytując w niepewnym otoczeniu, wypełnionym przez zmieniające się wartości, funkcjonujemy w stanach nierównowagi nie tylko między tymi wartościami, ale w sensie ich wpływu na nasze życie. Oddziaływanie kryzysu na życie powoduje, że z czasem uczymy się ograniczać sytuacje, które go wywołują, staramy się minimalizować jego skutki. W 2008 r. niektóre inicjatywy ustawodawcze rządu polskiego ukierunkowane pod wpływem sugestii 
KNF oraz NBP zostały wdrożone, choć nie było takiej potrzeby, ale dziś stanowią przydatny korpus mechanizmów, po który można sięgnąć na wypadek podobnej sytuacji załamania na rynku. Jednak z drugiej strony, do końca nie możemy być pewni, czy w innej rzeczywistości kryzysu nadal okażą się równie skuteczne. Mimo to świadomość pozostawania w dyspozycji skutecznego zespołu działań zapobiegawczych, instytucje te czyni lepiej przygotowanymi na ewentualne nieprawidłowości.

Przeciwnikom tezy o zawsze zgubnym wpływie kryzysu na naszą przestrzeń relacji społecznych można przedłożyć jedynie inną, równie pesymistyczną tezę, że kryzysu nie da się ani całkowicie przewidzieć, ani wyeliminować. Będąc zjawiskiem szczególnym, występującym w ramach ogólnego, czasami bardzo długiego procesu zmian, jakie wokół nas zachodzą - staje się towarzyszem na dobre i złe, czy tego chcemy, czy nie. Dlatego musimy to zjawisko uznać za nieodzowne od naszej ludzkiej natury i niekoniecznie akceptując, nauczyć się z nim żyć. Najczęstszymi źródłami kryzysu są: punkt zwrotny do zmiany na lepsze lub gorsze, znaczące emocjonalne zdarzenie lub radykalna zmiana statusu, moment decyzji, czy dane działanie będzie się toczyć dalej, czy nie, zagrożenie, obawa przed podjęciem jakiegoś ryzyka etc. Kryzys jest więc zdarzeniem nagłym lub narastającym, stanowi bowiem układ wydarzeń przyczyniających się do wzrostu zagrożenia, uniemożliwiających normalne funkcjonowanie, np. rynku finansowego, niosących zagrożenie dla interesów lub celów organizacji, przedsiębiorstwa, człowieka. W sensie społecznym stanowi kulminację wszechobecnych konfliktów, są one nieuniknione, zawierają się bowiem w strukturze społecznej.

Kryzys nie pozostawia społeczeństwa biernym i w tym sensie jest wyczekiwany, wymagając zmian i reorientacji co do podejmowania nowych wyzwań, tworzy nową sytuację, w której można upatrywać szansy na pozytywne rozwiązania. Rezonans sytuacji kryzysowej może ujawnić postawy zachowawczo-przystosowawcze, prowadzące do stanów rezygnacji i zaniechania, co odbywa się najczęściej ze złym skutkiem społecznym, rodzącym indyferentyzm lub wykluczenie. Choć każdy kryzys ma swój własny przebieg i dramaturgię, niektóre sekwencje działań pozostają podobne. Jedną z najważniejszych jest problem komunikacji społecznej. Chodzi więc o to, aby z koherentnej polityki zarządzania informacją uczynić fundament minimalizowania niepożądanych skutków kryzysu. W tym wypadku idzie o uczciwość i rzetelność przekazu. Truizmem jest dziś powiedzenie, że kondycja i wiarygodność banków opiera się na wzajemnym zaufaniu, dlatego przepływ informacji jest tak istotnym narzędziem w budowaniu tego zaufania, ale i kreowania jakości marki na rynku.

Wiele się mówi o tym, że skutki kryzysu w minimalnym tylko stopniu dotknęły sektor bankowy w Polsce. Jeśli wierzyć temu stwierdzeniu, to na ów sukces złożył się przede wszystkim wysoki poziom komunikacji społecznej, który nastąpił w najwłaściwszym momencie:

Stabilność polskiego rynku finansowego, która została potwierdzona w trakcie kryzysu, jest bowiem efektem wieloletniej konserwatywnej polityki nadzorczej przejawiającej się egzekwowaniem odpowiedniej ilości i jakości kapitałów instytucji finansowych. Wartością jaką udało się w Polsce zbudować, jest nadzór prowadzący dialog z rynkiem (Polski rynek..., 2010, s. 4).

Przy pewnym zastrzeżeniu metodologicznym dotyczącym treści pojęcia dialog ${ }^{*}$, z powyższymi konkluzjami trudno się nie zgodzić.

* Coraz częściej za dialog uznaje się zgoła niedialogiczne, niestabilne i efemeryczne kontakty międzyludzkie. Akty komunikacji oraz komunikacja nie stanowią jeszcze prawdziwego dialogu. Dialog bywa rozumiany jako rozmowa dwóch lub więcej uczestników, jednak chcąc podjąć refleksję nad rzeczywistą naturą dialogu, 
Warto zwrócić w tym miejscu uwagę na doniosłość perswazyjnych elementów języka, która złączona z umiejętnościami retoryki, jako najbardziej naturalne narzędzie dla dialogu, zdaje się odnosić sukces w różnych przestrzeniach życia społecznego. Retoryka jako sztuka skutecznego oddziaływania na odbiorcę okazuje się instrumentem sukcesu ekonomicznego, który wymaga mimo wszystko przygotowania, by w czasach kryzysu, jej skuteczność była zbieżna z oczekiwaniami społecznymi:

Perswazja jako sztuka skutecznego przekonywania jest językiem sukcesu, stając się dzisiaj swoistym lingwistyczno-kulturowym kodem sukcesu, którego opanowanie staje się niezbędne dla efektywnego funkcjonowania w środowisku biznesowym i społecznym (Lewandowska-Tarasiuk 2010, s. 59).

Ilekroć mówię o kryzysie rynków finansowych i bankowych, mam na myśli wydarzenia z 2007 r., których początkiem była zapaść na rynku pożyczek hipotecznych wysokiego ryzyka w USA. Były to głównie pożyczki hipoteczne udzielane hojnie przez banki przy wysokim ryzyku spłaty osobom o wątpliwej kondycji finansowej. Osiągnęły one status zabezpieczeń obligacji strukturyzowanych, które masowo sprzedawano dla celów inwestycyjnych i spekulacyjnych, zwłaszcza przez prywatne instytucje finansowe i największe banki w USA i Europie. Na ten stan nałożyła się bardzo niska świadomość ryzyka sprzedawanych obligacji, co miało związek z boomem na rynku nieruchomości. Firmy badające standing poszczególnych podmiotów (instytucje ratingowe) publikowały korzystne oceny bezpieczeństwa dla tego typu obligacji. Skutek był taki, że rozpoczął się groźny proces niewypłacalności dłużników indywidualnych $(9,2 \%)$, co uruchomiło efekt braku gotówki na rynku kredytowym i zagroziło stabilności finansowej. Wraz z tymi zjawiskami wszczęto debatę, której konkluzje były jednoznaczne: nastąpiło zagrożenie niewypłacalności wierzytelności przez banki inwestycyjne.

Kryzys ze swej natury jest tylko pozornie zjawiskiem nieoczekiwanym. W przypadku ostatnich wydarzeń upadek Lehman Brothers, choć szacuje się, że był najpoważniejszym globalnym kryzysem finansowym po wojnie, w jakiejś mierze dał się przewidzieć. Nadmierna ufność do kredytobiorców i wiara w ich dobrą wolę, jeśli nie była czystą naiwnością, musiała rodzić refleksje co do długości trwania prosperity. Jeśli stawiamy pytanie, jak długo coś będzie trwało, to przecież sama forma tego pytania zawiera wątpliwość, obawę lub zakładany koniec trwającego stanu rzeczy. Byłoby więc czymś nie do pomyślenia, aby sądzić, iż ekonomiści banku nie zdawali sobie sprawy z potencjalnego zagrożenia. Wielce prawdopodobne, że krach nastąpił znacznie szybciej niż się tego spodziewano. Tym bardziej cieszy mądra polityka finansowa polskich banków, której zarzucano zbytnią ostrożność i konserwatyzm. Jak widać, była to po prostu dojrzałość przejawiająca się przede wszystkim w autonomii, pozwalającej na ostrożne kroki przy podejmowaniu ryzyka, odporność na zewnętrze i nagłe

jako wejściem w głębokie, niepowtarzalne i intymne relacje międzypodmiotowe, należy zjawisko to dookreślić i zdefiniować. O dialogu coraz częściej mówi się w szkołach, na uczelniach, słyszymy o toczącym się dialogu ekumenicznym czy społecznym, ale określenie to używane w tych kontekstach najczęściej zastępuje słowa: kontakt, współdziałanie, partnerstwo, komunikacja, tolerancja, wymiana, negocjacje itp. Żeby wydobyć bogactwo rzeczywistych treści pojęcia dialog, należy przede wszystkim wskazać jego cechy konstytutywne, zakreślić jego granic, przybliżyć sytuacje kontekstowe, w jakich jest on możliwy, określić jego potencjalne zagrożenia, sięgnąć do źródeł spotkania w duchu dialogu. Dopiero wówczas to, co znajdzie się poza taką kategoryzacją będziemy mogli oddzielić od treści pojęciowej dialogu. Komunikacja społeczna, do której odnosi się cytowany powyżej fragment, w moim przekonaniu, dalece nie spełnia kryteriów dialogu jako relacyjnego ze swej istoty autentycznego spotkania i wydarzenia międzypodmiotowego. 
oznaki wahnięć, stabilność systemu finansowego, a także płynność w sektorach ubezpieczeniowym i bankowym.

Jeśli kryzys jest nagłym odstępstwem od względnego stanu stabilizacji, wyzwala także mechanizmy obronne, skierowane ku zachowaniu jak najdłużej status quo, gdy to się nie udaje, zmierzają one do maksymalnego zabezpieczenia stanu posiadania, co jest najbardziej uchwytne i mierzalne w sensie ekonomicznym. Ale kryzys to także zjawisko dokonujące zmian w obrębie świata wartości, zmuszające do reorientacji etycznej - albo utwierdza nas co do przyjętych i akceptowanych pryncypiów moralnych, albo ujawnia ich nieadekwatność. Z perspektywy zmieniającej się dynamicznie struktury świata mogą one ukazać swą niemoc i nieskuteczność. Intrygujące jest więc pytanie, czy po kryzysie jednostka pozostaje taka sama? I tak, i nie. Kryzys zmusza do działania, będącego następstwem racjonalnej refleksji i w tym sensie nowe doświadczenie rodzi nową istotę. Jednak w przypadku skuteczności wyznawanych przez nas wartości kryzys utwierdza nasze przywiązanie do nich, petryfikując przyjęte niegdyś sądy wartościujące i pozwalając na zachowanie nas takimi samymi (możliwe, że bardziej autentycznymi), czyli osobami sprzed kryzysu.

Przyczyny kryzysu tkwią, jak sądzę, w sferze społecznej. W ostatnich latach dominującym trendem w USA i krajach Europy Zachodniej stał się rozbudzany poprzez różne strategie marketingowe i medialne model niepohamowanej konsumpcji. Co istotne, intensyfikacja działań społeczeństwa na rzecz nabywania większej ilości dóbr konsumpcyjnych miała miejsce nie dzięki zwiększonemu poziomowi dochodów, stopy życiowej lub oszczędności, ale za sprawą życia na kredyt. Korzenie tej nowej fali bogactwa pozbawione były racji w gospodarce realnej, powstawały bowiem głównie w obszarze instrumentów finansowych. Euforyczne stany głoszące sukces ekonomiczny miały swe źródło w przekonaniu o wartości umiejętnego inwestowania. Mądre inwestycje miały więc zapewnić spore dochody. Chęć zysku za wszelką cenę, tu: za cenę niewiarygodnego ryzyka, stała się przyczyną załamania gospodarczego. Po raz kolejny stara grecka zasada złotego środka objawiła swą uniwersalną i ponadczasową mądrość. Ponadto niezwykłe przyspieszenie sektora finansowego w stosunku do gospodarki realnej w ostatniej dekadzie spowodowało utratę równowagi między tymi sferami. Może warto w tym kontekście ponowić pytanie o zrównoważony rozwój?

\section{KRYZYS CZY KRYZYSY?}

Analizując i interpretując ostatnie wydarzenia na rynkach światowych, można odnieść wrażenie, że zasadniej jest mówić o kryzysach niż kryzysie. Liczba mnoga ustrzega nas, jak sądzę, przed zbytnią subiektywizacją oraz pokazuje wielokierunkowość tego zjawiska, zwraca również uwagę na różnorodność jego źródeł. Multiplikacja źródeł zachodzi paralelnie do wielości procesów globalnych, takich jak integracja sektora bankowego, polityki, gospodarki czy interkulturowość. Można więc postawić tezę, że kryzys ujawniający się nade wszystko w świecie międzynarodowej finansjery, z punktu widzenia procesów globalizacji jest zjawiskiem naturalnym, wobec czego zakładanym i poniekąd oczekiwanym, co wcale nie oznacza, że pożądanym. W tym więc kontekście wciąż nie do końca zrozumiały jest klimat towarzyszący temu zjawisku: zaskoczenie bądź zdziwienie. Kryzys, będąc faktem socjologicznym, jako zjawisko społeczne dotyka przedstawicieli różnych społeczeństw. Rodzi więc zarówno skutki pozytywne, jak i - co na pewno groźniejsze - negatywne. Trudno 
jest więc w sposób arbitralny jednoznacznie wykazać, w jakiej sferze życia społecznego przyniósł te najgorsze. Dotykamy tu, jak sądzę, starego problemu metodologicznego, mianowicie nieprzekładalności dyskursów oraz - obok czynników ilościowych (ekonomicznych) - braku jednoznacznych kryteriów oceny wyników poszczególnych zjawisk o charakterze kryzysu na różne sfery życiowej praxis. Zgoła inaczej należy patrzeć na problem wpływu kryzysu ekonomicznego na kondycję psychiczną uczestników życia społecznego, szczególnie wziąwszy pod uwagę np. ich dotychczasowe status quo, stanowisko, zakres odpowiedzialności oraz ryzyko utraty stanu posiadania. U każdej z tych osób rezonans kryzysu ujawnił się z różną siłą i na różne sfery życia inaczej oddziałał.

Z perspektywy wielkich przedsiębiorstw kryzys najczęściej implikuje cięcia budżetowe, zmiany w polityce socjalnej, redukcje w sferze zatrudnienia. Jeśli mimo to podmiot pozostaje aktywnym uczestnikiem na rynku pracy, kryzys nie ujawni swej destrukcyjnej siły, jak w przypadku utraty zatrudnienia. Machina medialna, przekazująca nieustannie informacje o stanie kryzysu, bezsprzecznie wpływa na podwyższony poziom emocjonalny, wynikający z wewnętrznego poczucia strachu przed marginalizacją, a w konsekwencji wykluczeniem. Żadne przedsiębiorstwo w zglobalizowanym świecie nie działa w próżni i samotnie, coraz gorsza kondycja jednego podmiotu jest w stanie znacząco wpłynąć na inny, szczególnie gdy podmiot ten sytuuje się na granicy upadłości. Płynąca z założeń procesu globalizacji zasada naczyń połączonych może, z punktu widzenia ekonomii, okazać się systemowym przekleństwem. Wśród ekonomistów, co w pewnym sensie jest uzasadnione, odczuwa się przede wszystkim troskę o kapitał oraz implicite o jego właścicieli: czy znajdą alternatywne sposoby prowadzenia przedsiębiorstw w nowych warunkach rynkowych, czy środki, jakimi dysponuja, nie przepadną, czy nie znikną z rynku? Upadłość podmiotu gospodarczego nie jest upadłością li tylko akcjonariatu, ale rodzi znacznie poważniejsze skutki w dziedzinie społecznej:

Upadłość jest problemem społecznym, gdyż jej negatywne skutki dotykają znacznie większej liczby uczestników życia gospodarczego, aniżeli tylko samych właścicieli przedsiębiorstwa upadłego. Żaden podmiot gospodarczy nie działa w oderwaniu od otoczenia. Problemy finansowe jednej firmy dotykają wszystkich jej pracowników, dostawców, odbiorców, a także społeczeństwa, gdyż likwidacja przedsiębiorstwa oznacza pojawienie się na rynku pracy nowych bezrobotnych (Bauer 2010, s. 209).

O kryzysie, jego naturze, przebiegu oraz skutkach ekonomicznych pisze się ostatnio sporo, jest to tym bardziej zrozumiałe, że problem jest odczuwalny i dotyczy zdarzeń aktualnych. Mimo to nie sadzę, aby najnowsze prognozy były w stanie ująć wszelkie możliwe do zaistnienia w przyszłości czynniki. Z uwagi na intensyfikację postępu technicznego, miniaturyzację aparatów działających w systemach cyfrowych, przyspieszenie w zakresie zmian społecznych i kulturowych, a także politycznych, żaden ośrodek badawczy nie jest w stanie w pełni przewidzieć nowych możliwych zagrożeń, choćby z tej przyczyny, że nowości i zmiany w powyższych dziedzinach generują nowe zagrożenia, które jeszcze się nie ujawnity.

Pewnym rozwiązaniem znacznie ograniczającym ekspansywność negatywnych skutków kryzysu gospodarczego byłoby postulowane przez coraz większą rzeszę naukowców wdrożenie zasad tzw. nowej etyki, czyli pozytywnej odpowiedzi na zmieniające się potrzeby i zagrożenia rynku (Laszlo 2008). Są nimi zasady oparte na rzeczywistych i niepodważalnych wartościach, będące zarazem apelem o włączenie zrównoważonych wartości, szczególnie w kontekście doświadczenia negatywnych skutków globalizacji po upadku Lehman Brothers. 
Fakt ten potwierdza potrzebę stworzenia swoistego modus operandi w wymiarze ogólnoplanetarnym i globalnym. Jak fala kryzysu rozlała się po świecie, tak zrównoważony rozwój nie pozwoliłby naruszyć równowagi żadnej ze sfer podległych zrównoważonej kontroli:

Szansą dla utwierdzenia zrównoważonych wartości w momencie transformacji przemysłu i usług jest fakt, ze nowa etyka staję się bez mała etyką globalną i ogólnoplanetarną zarazem, bowiem kodeks, który wytycza przyszłe drogi biznesu, zostaje rozszerzony na obszar całej kuli ziemskiej. Problemy, których dotyka, nie ograniczają się jedynie do obszarów lokalnych, ale obejmują odpowiedzialność firmy za środowisko i społeczeństwo, dotyczą więc biosfery i populacji całego świata (Brzozowski 2010, s. 220).

W powszechnej niemal opinii drastyczne skutki kryzysu szczęśliwie ominęły Polskę, choć z cała pewnością do końca nie można tego jednoznacznie stwierdzić. Zasięg czasowy niektórych zjawisk jest znacznie rozciagnięty i możliwe, że z czasem ujawni nowe nieprawidłowości. Badając poszczególne efekty kryzysu w zakresie gospodarki finansowej na rodzimym rynku, można je zredukować do trzech najistotniejszych. W sferze bankowej mocno odczuwalne było zastopowanie normalnych funkcji rynku międzybankowego, spowodowane głównie kryzysem zaufania. I tak oto kryzys finansowy zapoczątkował inny kryzys, kryzys w relacjach międzyinstytucjonalnych (market seizure) i w konsekwencji międzyludzkich. Doprowadziło to do zjawiska przechwycenia rynków przez silne podmioty kosztem utraty klientów przez mniejsze banki.

$\mathrm{Na}$ tę niekorzystną społecznie sytuację kryzysu zaufania nałożyły się informacje o gwałtownej zmianie cen na rynkach finansowych, szczególnie o spadku cen akcji i osłabieniu kursów walut państw wchodzących w fazę rozwoju gospodarczego (market dislocation). Ostatni problem dotyczył także polskiego złotego. Ale paradoksalnie, a zgodnie z główną tezą niniejszego artykułu, to pozornie negatywne zjawisko przekształciło się w element pozytywny, mianowicie deprecjacja złotego spowodowała bardzo korzystny efekt w sensie podniesienia poziomu konkurencyjności rodzimych podmiotów trudniących się eksportem. Ten przykład pokazuje, że złagodzenie kryzysu w sferze realnej jest możliwe, bowiem dzięki atrakcyjności cenowej towarów eksportowanych, przy wyjątkowo sprzyjającej sytuacji rynkowej, wywołanej negatywnym w gruncie rzeczy czynnikiem kryzysowym, polska gospodarka zaczęła znacząco się stabilizować. Mimo odnotowanych spadków w skali średniej światowej eksportu, przychody polskich eksporterów znacząco wzrosły. Z punktu widzenia ekonomii zjawisko to nie jest czymś wyjątkowym. W zależności od interpretacji, w tym przypadku kryzys zainicjował pozytywny impuls dla sektora eksporterów.

Nie oznacza to oczywiście, że w innych sferach było równie dobrze. Wciąż pozostajemy w sytuacji braku kryteriów dla równomiernego porównania wielu efektów. Trudno powiedzieć, czy to specyfika polskiej gospodarki, czy jakiś ukryty efekt innych czynników wywołał dość nieoczekiwane skutki, niekoniecznie en bloc negatywne. Inny przykład to dane wskazujące, że przy wzroście stopy bezrobocia wzrosło PKB, co zakrawało na mały cud gospodarczy, choć i ten ma swe uzasadnienie, np. w postaci faktu zwiększenia wydajności polskiego pracownika. Na koniec warto zwrócić uwagę na trzecią grupę efektów, mianowicie na wyniki w strefie realnej (spillover effects) (Polski rynek... 2010, s. 8). Chodzi tu przede wszystkim o tendencje spadkową popytu zewnętrznego i znaczne pogorszenie warunków w dostępie do kredytów. Wpłynęły na to zwyżki prowizji bankowych, podniesienie poziomu zabezpieczeń, których domagały się banki, oraz drakońską ocenę tzw. zdolności kredytowej i równie wysokie marże na uruchomienie różnych produktów bankowych. Odczuwalne 
trudności w dostępach do kredytów komercyjnych dały o sobie znać na początku roku 2009, zatem bankowe procedury antykryzysowe były mocno spóźnioną reakcją na wydarzenia na światowych rynkach. Pomimo tego ich skuteczność przyniosła pożądany rezultat. Niepokojącą sytuację rynku znacznie poprawił będący na plusie w stosunku do dynamiki PKB polski eksport oraz utrzymująca się na wysokim poziomie konsumpcja. Należy też pamiętać o tzw. wojnie depozytowej z września 2008, która podniosła poziom konkurencyjności między bankami, a skutkowała zwyżką kosztów pozyskania depozytów.

Wymienione tu (nie wszystkie rzecz jasna) czynniki ujawnione podczas trwania ostatniego kryzysu są najlepszym dowodem, że w czasach globalizacji nie można już mówić o kryzysie jako jednym zjawisku, ale raczej o wielości kryzysów, wśród których występują czynniki odpowiedzialne za wpływ w skali makro, ale i te ujawniające się tylko lokalnie, odgrywające role mikrokryzysów, jednak tak samo groźnych, bo niedających się przewidzieć z perspektywy rynków światowych, dlatego tym trudniej jest zwalczać ich skutki lub przedsiębrać działania o charakterze profilaktycznym.

\section{KRYZYS SPOŁECZNY CZY SPOŁECZEŃSTWO KRYZYSU?}

Z punktu widzenia społeczeństwa, kryzys gospodarczy kojarzony jest przede wszystkim ze wzrostem cen lub stopy bezrobocia. Dochodzą do tego większe trudności w otrzymaniu kredytów detalicznych, zatem bywa czasem niesprzyjający inwestowaniu lub alokacji środków w akcje lub zagraniczne waluty. Ceny walut o dużym stopniu ryzyka czy aktywów znacznie się obniżają, zyskują zaś ceny złota lub srebra oraz tzw. waluty bezpieczne (jen japoński, frank szwajcarski). Podczas ostatnich wydarzeń dał się zauważyć popyt na obligacje emitowane głównie przez rząd USA. W Polsce w okresie od września 2008 r. do początku 2009 r. o połowę spadł Warszawski Indeks Giełdowy.

Można zadać pytanie, na ile powyższe informacje wpłynęły znacząco na zmiany w świadomości przeciętnego obywatela? Jeśli ktoś prowadził przedsiębiorstwo, musiał się zetknąc $\mathrm{z}$ utrudnionym dostępem do kredytu bankowego, jeśli był w momencie starania się o kredyt komercyjny, spotkał się z coraz wyższymi oczekiwaniami ze strony banków co do zabezpieczenia kredytu lub bank odmówił mu udzielenia pożyczki, zwłaszcza wówczas gdy chciał ją otrzymać w walutach innych niż złoty. Również kierowcy bardzo szybko zauważyli zwyżkę cen paliw płynnych na stacjach paliwowych. Wymienione zjawiska, z natury rzeczy negatywne społecznie, nie są jedynymi problemami odziedziczonymi po okresie załamania gospodarczego w ostatnim czasie. W kształtowaniu negatywnych nastrojów społecznych niemałą rolę odegrała kampania medialna, rozpętana na rzecz utrzymywania społeczeństwa w świadomości, że krach banku amerykańskiego spowodował wielkie straty na całym świecie, co z siłą uderzy także w kraje Europy Środkowej. W niedługim czasie pojawiły się problemy finansowe w Islandii oraz Irlandii, a ta ostatnia dla młodej polskiej emigracji miała być panaceum na wyrównanie szans na starcie.

Jak oszacować rzeczywisty wpływ kryzysu na sferę społeczną? W sensie zatrudnienia nie obyło się bez redukcji, ale nie były one tak drastyczne, jak zapowiadały najczarniejsze scenariusze. Utrzymywanie społeczeństwa w nieustannym klimacie zagrożenia zrodziło chyba gorsze skutki niż te wywołane w tzw. sferze realnej. Myślę tu o zmianach świadomościowych. Na ich tle można dostrzec w Polsce rozkład zachowań o charakterze obywatelskim, 
z którym, szczególnie u początku transformacji ustrojowej, były już kłopoty. Ponadto socjologowie notują najniższy od wielu lat poziom zaufania społecznego u Polaków. Na te zjawiska nałożyły się anomalie pogodowe, które w ostatnim roku (roku trwania kryzysu) odebrały niektórym mieszkańcom nadzieję oraz zaufanie do państwa, niepotrafiącego sobie poradzić ze skutkami powodzi oraz wsparciem socjalnym dla najbardziej dotkniętych, o czym świadczą doniesienia mediów o dużej liczbie nieukończonych remontów zalanych mieszkań (Bogatynia, Sandomierz). Polska państwowość w kwietniu 2010 r. w katastrofie lotniczej utraciła wielu najwyższych przedstawicieli, zrodziła się również obawa o utrzymanie stanowisk w zakładach Fiata, pozostał problem niedomkniętej umowy na dostawy gazu.

W moim przekonaniu, dziś jednoznaczna i adekwatna odpowiedź na pytanie o skutki społeczne kryzysu gospodarczego nie jest możliwa. $Z$ jednoznacznymi opiniami trzeba się wstrzymać. To problem złożony i rozciagnięty w czasie. Z punktu widzenia jednostki kryzys nie jest wyrazisty (wzrost poziomu konsumpcji), ale na pewno zrodził świadomość niepokoju i niezrozumienia. Mimo napływu treści o rozszerzających się procesach globalnych, postępującej informatyzacji itp. wielu ludziom wciąż trudno zrozumieć, jak wydarzenia na jednej półkuli mogą mieć tak ogromny wpływ na pozostałe kraje i ich gospodarki. Brak orientacji w tendencjach gospodarki światowej oraz niezrozumiałe procesy stają się źródłem wielu społecznych napięć i niepokojów. To wynik niskiej świadomości tego, co się wokół nas dzieje. Ekonomii i najprostszych mechanizmów rządzących gospodarką globalną nie da się zredukować do postulatów ochrony środowiska, kontrowersyjnego zresztą, zmniejszenia emisji gazów cieplarnianych czy wezwań do segregowania śmieci.

Istnieje realna potrzeba wyposażenia społeczeństwa w podstawową wiedzę o procesach rynkowych. Rzetelna forma przekazu być może pozwoli uspokoić nastroje i przenieść ciężar wzajemnych podejrzeń w stronę ludzkiej solidarności i wrażliwości na niedostatek innych. Potrzebny jest powrót do wartości podstawowych i szerszej edukacji. Zamiast mówić o wpływie kryzysu na społeczeństwo, co niewątpliwie ma miejsce, można też mówić o społeczeństwie kryzysowym, tj. dotkniętym przez szereg kryzysów, nie tylko gospodarczych, z którymi musi się ono nauczyć żyć. Można by było wrócić w tym miejscu do greckiego określenia, które znacznie rozszerza pole semantyczne tego słowa, nie zacieśniając go do zjawisk stricte ekonomicznych. Kryzys gospodarczy, z jakim mamy obecnie do czynienia, jest jednym $\mathrm{z}$ wielu trawiących współczesne społeczeństwa. Tym trudniej jest więc zdefiniować i ustalić, który z nich jest najgroźniejszy.

\section{KRYZYS(-SY) I GLOBALIZACJA WOBEC PRZYSZŁOŚCI}

Kryzys gospodarczy w skali międzynarodowej rozwiał wszelkie iluzje co do możliwości osiągnięcia porozumienia i spokoju. Ujawnił znaczne zwiększenie zadłużenia publicznego oraz tendencje w oczekiwaniach, których kierunkiem jest własność państwowa wraz z możliwością zmiany systemu wartości. Problem kryzysu przytłumił najważniejsze - jak można było do niedawna sądzić - zagrożenia cywilizacyjne, do których zaliczano globalne ocieplenie, niedobór surowców i energii oraz ich wysokie ceny. Wygasła też aktywność rzeszy ekonomistów nakierowana na poszukiwanie nowych rozwiązań w powyższych obszarach, co w niedługiej przyszłości może okazać się bardzo zgubne.

Inne ze zjawisk wyraźnie przyspieszyły. Przeniesiono centra finansowe do Azji, nastapiły też zmiany w zarządzaniu zglobalizowanym światem. Rzecz jasna, chodzi o utratę znaczenia 
państw grupy G8 na rzecz grupy G20, czyli de facto o zainicjowanie procesów powstawania nowego układu sił na świecie. W obszarze sektora finansowego doszło do radykalnej wolty: od bardzo odważnego pożyczania środków do przesadnie konserwatywnych zachowań. W najbliższym czasie, jak można prognozować, będziemy obserwować zwrot w stronę nowych wartości, do których przynależy wciąż aktualny postulat zrównoważonego rozwoju. Pora wrócić do modelu wzrostu dochodów poprzez silną pozycję rynku pracy i sukcesów biznesu w sferze realnej gospodarki, odchodząc od probierza poziomu rynków finansowych, czego nauczyły aż nazbyt boleśnie ostatnie wydarzenia w skali międzynarodowej. Nie bez winy są też media, które zamiast przekazywać rzetelne, oparte na faktach i rzeczywistości realnej (nie wirtualnej) informacje, coraz częściej wykorzystują swą „magiczną” moc przekształcania rzeczywistości realnej w wyimaginowaną, która zaczyna żyć swoim życiem w naszych umysłach. Tak tworzy się swoista maszyneria przekształceń nie liczących się z danymi rzeczywistymi.

Również podmioty funkcjonują jak maszyny, filtry i kanały, służące strumieniom informacji docierających do naszych zmysłów na najrozmaitszym poziomie odbioru. Podmiot oraz świat dostają się tym samym w wir podwójnego upłynniania, w ontologiczne rozkołysanie znajdujące wyraz w tysiącach nowoczesnych teorii kryzysu (Sloterdijk 2008, s. 534).

\section{Literatura}

Bauer K., 2010, Kryzys finansowy a restrukturyzacja przedsiębiorstw w stanie upadtości, [w:] Procesy transformacji przemystu $i$ uslug $w$ regionalnych $i$ krajowych ukladach przestrzennych, red. Z.Zioło, T. Rachwał, Prace Komisji Geografii Przemysłu Polskiego Towarzystwa Geograficznego, nr 15, Warszawa-Kraków.

Brzozowski T.T., 2010, Koncepcja zrównoważonego rozwoju wyzwaniem dla procesów transformacji przemystu i ustug, [w:] Procesy transformacji przemystu i ustug $w$ regionalnych i krajowych uktadach przestrzennych, red. Z. Zioło, T. Rachwał, Prace Komisji Geografii Przemysłu Polskiego Towarzystwa Geograficznego, nr 15, Warszawa-Kraków.

Laszlo Ch., 2008, Firma zrównoważonego rozwoju, EMKA, Warszawa.

Lewandowska-Tarasiuk E., 2010, Język przestrzeni publicznej, [w:] Pedagogika dialogu. Doświadczenie dialogu w rzeczywistości XXI wieku, red. E. Dą̧rowa i D. Jankowska, Warszawa.

Polski rynek..., 2010, Polski rynek finansowy w obliczu kryzysu finansowego w latach 2008-2009, Materiały i opracowania Urzędu Komisji Nadzoru Finansowego, Warszawa.

Sloterdijk P., 2008, Krytyka cynicznego rozumu, przeł. P. Dehnel, Wrocław.

Stownik grecko-polski, 2000, oprac. O. Jurewicz, t. 1, PWN, Warszawa.

Zasoby internetowe

http://www.pfo.net.pl/iii-pomorski-kongres-obywatelski/wystpienia-i-sprawozdania/115-kryzysgospodarka-spoeczestwo (dostęp 29.12.2010) 


\section{Crisis as a philosophical and social problem}

The article deals with the crisis and its effects. The results of the crisis do not always have to be unfavorable. The author of this text puts forward the thesis, that the effects of the crisis can sometimes lead to good results. The point of view depends on interpretation.

In philosophical and social sense each slump requires somebody to take an action. Moreover, if the industry is in good condition, such state will not last forever. It is hard to explain why the last economic crisis triggered off such strong emotions. This crisis could be predicted and was, in a sense, expected. In author's opinion it is worth to look on the positive side of the crisis as well.

Dr Tomasz Tadeusz Brzozowski

Wałbrzyska Wyższa Szkoła Przedsiębiorczości i Zarządzania

Wyższa Szkoła Technologii Teleinformatycznych, Świdnica

e-mail: tomasz.tadeusz.brzozowski@ala.art.pl lub Tomasz.Brzozowski@wstt.edu.pl 